\title{
Excess Credit and the South Korean Crisis
}

\author{
Panicos O Demetriades ${ }^{1}$ \\ and Bassam A Fattouh ${ }^{2}$
}

August 2006

\begin{abstract}
We provide a novel empirical analysis of the South Korean credit market that reveals large volumes of excess credit since the late 1970s, indicating that a sizeable proportion of total credit was being used to refinance unprofitable projects. Our findings are consistent with theoretical literature that suggests that soft budget constraints and overborrowing were significant factors behind the Korean financial crisis of 1997-98.
\end{abstract}

Keywords: over-borrowing, South Korea, financial crisis

JEL classification: G18, O16

Copyright (C) UNU-WIDER 2006

${ }^{1}$ University of Leicester, UK. ${ }^{2}$ CeFiMS, SOAS, London.

This study has been prepared within UNU-WIDER's research on Globalization, Finance and Growth, linked to the project on Financial Sector Development for Growth and Poverty Reduction.

UNU-WIDER gratefully acknowledges the financial contributions to the research programme by the governments of Denmark (Royal Ministry of Foreign Affairs), Finland (Ministry for Foreign Affairs), Norway (Royal Ministry of Foreign Affairs), Sweden (Swedish International Development Cooperation Agency_Sida) and the United Kingdom (Department for International Development). 


\section{Acknowledgements}

We have benefited from discussions with a number of International Monetary Fund and World Bank economists, especially Charles Adams, Tomás José Boliño, Eduardo Borensztein, Jim Gordon, Giovanni Ferri, Tae-Soo Kang, and Joe Stiglitz. Naturally, all views expressed in this paper as well as any errors are solely our own. We are grateful to the Economic and Social Research Council (ESRC) and South Bank University for financial support.

The World Institute for Development Economics Research (WIDER) was established by the United Nations University (UNU) as its first research and training centre and started work in Helsinki, Finland in 1985. The Institute undertakes applied research and policy analysis on structural changes affecting the developing and transitional economies, provides a forum for the advocacy of policies leading to robust, equitable and environmentally sustainable growth, and promotes capacity strengthening and training in the field of economic and social policy making. Work is carried out by staff researchers and visiting scholars in Helsinki and through networks of collaborating scholars and institutions around the world.

www.wider.unu.edu publications@wider.unu.edu

UNU World Institute for Development Economics Research (UNU-WIDER)

Katajanokanlaituri 6 B, 00160 Helsinki, Finland

Camera-ready typescript prepared by Adam Swallow at UNU-WIDER

The views expressed in this publication are those of the author(s). Publication does not imply endorsement by the Institute or the United Nations University, nor by the programme/project sponsors, of any of the views expressed. 
A number of recent theoretical papers, including McKinnon and Pill (1997), Corsetti et al. (1999), Huang and Xu (1999), and Schneider and Tornell (2004) have analyzed the role of over-investment and over-borrowing in financial crises. McKinnon and Pill (1997) argue that in an inadequate regulatory framework, banks can inflate entrepreneurs' expected payoffs, knowing that in case of default the government will be forced to bail out distressed borrowers. The entrepreneurs, lacking sufficient information to assess banks' signals, tend to consider them as correct. As a result, they bid eagerly for funds and a lending-investment boom ensues. In Corsetti et al. (1999) analysis, a financial crisis erupts as a result of potential future fiscal deficits that are implied by moral hazard behaviour in private corporate and financial investment. The latter leads to over-investment, which can persist for as long as domestic firms are able to refinance their unprofitable projects and cash shortfalls through foreign borrowing - a process known as 'evergreening'. Only when international reserves fall below a certain threshold1, foreign investors' willingness to rollover credit would cease, causing a financial crisis. In a similar vein Huang and Xu (1999) argue that over-investment in South Korea was due to soft budget constraints, which enabled large industrial conglomerates (chaebols) to have continuous access to subsidized policy loans. In such an economy, there is no mechanism to ensure that bad projects are terminated because bad signals are not revealed to investors or depositors, creating unduly optimistic expectations. Hence, loss making projects can be hidden for a long time by overborrowing. These problems only become apparent when an exogenous shock hits the economy.

This paper provides an empirical investigation of the over-borrowing hypothesis in South Korea using a novel approach. Specifically, our modeling strategy takes into account the institutional characteristics of the South Korean credit market, including the direct effects of financial repression that were prevalent until the late 1980s. Additionally, we utilize time series econometric techniques that allow us to construct a measure of short-run disequilibrium in the credit market. 2 Unlike previous attempts to model disequilibrium behavior in the credit market that rule out the presence of a realized excess supply by assumption, our approach allows the actual stock of credit to be above or below its long-run equilibrium value, which is determined by economic fundamentals.

Our results show that, with few exceptions, the Korean credit market had been characterized by excessive credit creation since the late 1960s. That is to say, the actual stock of credit is found to be greater than its long-run equilibrium level predicted by economic fundamentals, such as real economic activity and the cost of credit. Our estimates of excess credit may be interpreted as measures of 'unproductive credit' in the sense that it was not used to finance productive economic activity. The presence of

1 In Corsetti et al. (1999), the threshold is expressed as a fraction of implicit government liabilities which mainly arise due to excessive foreign borrowing by the private sector and over-investment in low productivity projects. It is interesting to note that these implicit government liabilities can coexist with a low public debt and budget deficit.

2 See for example Hendry (1995) or the papers in the Engle and Granger (1991) edited volume. 
excess credit indicates the existence of loss-making projects that were continually being refinanced by banks. Thus, our empirical findings are consistent with the theoretical predictions of Huang and Xu (1999) and Corsetti et al. (1999).

The rest of the paper is organized as follows. Section 2 discusses some methodological issues while section 3 presents the empirical specification and results. The last section summarizes and concludes.

\section{Methodological issues}

In evaluating whether a credit market is characterized by disequilibrium conditions previous empirical studies, such as Laffont and Garcia (1977) and Pazarbasioglu (1996), have used the model of supply and demand from Maddala and Nelson (1974). This approach assumes that in some markets, prices are not perfectly flexible and hence disequilibrium could occur. In the absence of any information concerning the priceadjustment process, the probability with which each observation belongs to the demand or supply function is determined by assuming that the short side of the market is never rationed. Maddala and Nelson (1974) derive the appropriate maximum likelihood method for this class of models.

By stipulating that the long side of the market is the one that is rationed, the traditional disequilibrium approach, while allowing for notional excess supply, has ruled out the possibility of an effective excess supply of credit. That is to say, in the traditional approach an excess supply of credit can only represent the case in which banks would like to supply more credit than firms are willing to accept; thus, without coercion, an excess supply of credit can never be realized. In practice, however, excessive credit creation may refer to the possibility that firms take on more credit than is predicted by the long-run determinants of the demand for credit - which typically include the cost of credit and an indicator of real economic activity. Excess credit - which we define to be the excess of actual credit to the amount predicted by the long-run demand for credit may be the result of loss-making projects that are continually being refinanced by banks. The main reason why banks refinance unprofitable projects is their reluctance to admit publicly that they have problematic assets, which would reduce their stock market value and hamper their ability to raise capital. In extreme cases, when the amount of non-performing assets exceeds shareholders' capital, admitting the presence of problematic loans is tantamount to declaring insolvency. In such circumstances, it is not unusual for banks to postpone taking action, in the hope that an economic upturn will allow firms to eventually repay their loans. Ultimately, of course, there is also the hope that when the problem threatens the soundness of many financial institutions and the stability of the financial system, some large corporates may be bailed out by the government. Thus, our notion of excess credit corresponds closely to the notion of overborrowing, reflecting soft budget constraints and/or moral hazard (Huang and Xu 1999; Corsetti et al. 1999).

The preceding analysis suggests that the effective or short-run stock of credit may well exceed the long-run desired demand for credit. It is, therefore, vital to allow for the possibility that a short-run observation may belong to neither the long-run demand nor the long-run supply function. In spite of the short-run deviations from long-run equilibrium, it is nevertheless plausible to expect to see some adjustment towards long- 
run market equilibrium for both demand and supply functions. 3 This is consistent with both theoretical and empirical work. For instance, despite the presence of information asymmetry, Laffont and Garcia (1977) find that the real interest rate has the tendency to adjust upwards when there is excess demand for credit. On the other hand, when there is an excess supply of credit, there is no reason why the interest rate should not fall to equilibrate the credit market (Greenwald et al. 1993).

Thus, in order to allow for the presence of unproductive credit, our estimation strategy differs from the traditional disequilibrium approach outlined above in the following four important respects.

It assumes that in the long-run, the interest rate adjusts to equilibrate the credit market while allowing for departures from long-run equilibrium to occur in the short-run.

- $\quad$ It does not impose a priori restrictions on the speed of adjustment, which admits the possibility that the credit market may take a very long time to clear. Thus, the assumption that in the long-run market equilibrium prevails is not a restrictive one because how long the long-run is, is determined by the data.

- $\quad$ It does not depend on estimating a set of probabilities which are then used to locate an observation on the long-run demand or supply function. Instead, it identifies excess supply or demand by measuring the difference between the actual stock of credit and its predicted long-run equilibrium value, utilizing standard techniques in applied time-series econometrics.

- $\quad$ It allows the possibility that the actual stock of credit may exceed the long-run demand for credit, representing an excess supply of credit in the short-run, which the traditional disequilibrium approach does not admit.

\section{Empirical specification, data, and results}

In this section we specify a model for the long-run demand for and supply of bank credit, which takes into account the institutional characteristics of the South Korean credit market.

\section{The long-run supply of credit equation}

The real supply of loans in the long-run is assumed to be determined by the real lending interest rate $(r)$, the current level of economic activity, measured by real gross domestic product (GDP) (y), and the institutional characteristics of the credit market, measured by the degree of financial repression. The first two variables are widely used in empirical studies to capture respectively the profitability of banks' lending activities and their expectations about the state of the economy (Laffont and Garcia 1977; Pazarbasioglu 1996). The third variable has not been addressed in the empirical literature on credit markets (Pazarbasioglu 1996; Ghosh and Ghosh 1999), despite the presence of financial

3 In a way, this implies that any government policy providing financial guarantees to firms is eventually removed. 
restraints in almost all developing countries and some developed countries. Since the early 1960s, one of the most important institutional characteristics of the South Korean credit market has been the direct intervention of the state in the allocation and pricing of credit. 4 This was mainly achieved through controls on lending and deposit interest rates. Interest rate deregulation, which began in 1979, was only completed in the early 1990s. The impact of interest rate controls on the real supply of credit is not straightforward. In principle, lending rate controls, by limiting banks' profitability, may reduce the real supply of credit to the private sector. However, as noted by Caprio (1994), in the presence of higher interest rates, which usually follow financial liberalization, banks may choose to hold larger amounts of riskless assets and hence supply fewer loans to the private sector. Hence, the impact of the relaxation of lending rate controls on the supply of credit is ambiguous. The same conclusion holds for the impact of deposit rate controls on the supply of real credit, even though the reasoning is different. On the one hand, these controls limit the cost of funds for banks and hence increase the willingness of banks to supply increased amounts of credit. On the other hand, however, deposit rate controls limit the supply of funds to the banking system which, unless counteracted by other means, such as increased branching or marketing, are likely to reduce the ability of banks to supply increased amounts of credit.

In addition to interest rate controls, the South Korean government imposed reserve requirements on bank deposits (demand and/or time and savings deposits). Usually, the definition of bank reserves includes short-term government paper and/or central bank deposits, which typically yield a lower rate of return than bank loans. Hence, increases in reserve requirements raise the average cost of loanable funds and are, therefore, expected to result in an inward shift of the supply of credit to the private sector.

Thus, we use the following specification for the long-run supply of credit $\left(C^{s}\right)$ :

$$
C^{s}=\beta_{0}+\beta_{1} y+\beta_{2} r+\beta_{3} I R L+\beta_{4} R R+u_{t}
$$

where IRL is an index of interest rate restraints, $\mathrm{RR}$ is the required reserve ratio and $u_{t}$ is a white noise error term.

\section{The long-run demand for credit equation}

We assume that the long-run demand for (productive) credit depends positively on the level of real economic activity, measured by real GDP $(y)$, and negatively on the cost of credit, measured by the real lending rate $(r)$. Formally, we use the following specification for the long-run demand for credit $\left(C^{d}\right)$ :

$$
C^{d}=\alpha_{0}+\alpha_{1} y+\alpha_{2} r+v_{t}
$$

where $v_{t}$ is a white noise error term.

4 For a detailed discussion of the extent of financial repression in South Korea and its impact on financial development see Demetriades and Luintel (2001). 


\section{Reduced form}

We assume that in the long-run, the real interest rate is flexible enough to equate the real supply and demand for credit, that is, the exchanged quantity of credit is such that:

$$
C=C^{d}=C^{s}
$$

We next solve for the reduced form equation by substituting the value of $r$ from equation (2) in (1) to obtain the following:

$$
C=\gamma_{0}+\gamma_{1} y+\gamma_{2} I R R+\gamma_{3} R R+w_{t}
$$

where $\gamma_{0}=\left(\alpha_{2} \beta_{0}-\alpha_{0} \beta_{2} / \alpha_{2}-\beta_{2}\right)$

$$
\begin{array}{ll}
\gamma_{1}=\left(\alpha_{2} \beta_{1}-\alpha_{1} \beta_{2} / \alpha_{2}-\beta_{2}\right) ; & \gamma_{1}>0 \\
\gamma_{2}=\left(\alpha_{2} \beta_{3} / \alpha_{2}-\beta_{2}\right) & \gamma_{2}>0 \text { or } \gamma_{2}<0 \\
\gamma_{3}=\left(\alpha_{2} \beta_{4} / \alpha_{2}-\beta_{2}\right) & \gamma_{3}<0
\end{array}
$$

\subsection{Data}

The dependent variable is measured by (the logarithm of) broad claims on the private sector deflated by the GDP deflator. Real broad credit constitutes claims on the private sector by deposit money banks, trust accounts of commercial banks, development banks, and non-bank financial institutions. The data source for these variables, as well as for real GDP and the GDP deflator, is the International Financial Statistics (IMF 1998: 6).

The construction of the index of interest rate restraints utilizes the detailed information about financial reforms summarized in Appendix A, which was obtained from Bank of Korea Annual Reports (various issues). The index is assumed to take a value of unity prior to any relaxations, and decreases in value whenever restrictions on interest rates are relaxed or removed; it is therefore increasing with the severity of financial restraints, and decreasing as financial liberalization progresses. Initially, we constructed separate indices for controls on deposit rates, lending rates, and money market rates. Since these indices were found to exhibit strong positive correlation between them, we averaged them out into a single measure, which we call 'the interest rate restraints index'. This measure is plotted in Figure 1. Its movements reflect the changes in the underlying policy variable reasonably well. The relaxation of lending controls in 1979 is reflected in a drop in the measure for that year. The measure then exhibits relative stability until 1988, when it drops sharply following the liberalization of interest rates on lending and certain types of time and savings deposits. Further drops are observed in the early 1990s reflecting further deregulation in deposit rates and lending rates on policy loans. 
Figure 1: Summary measure of interest rate restraints

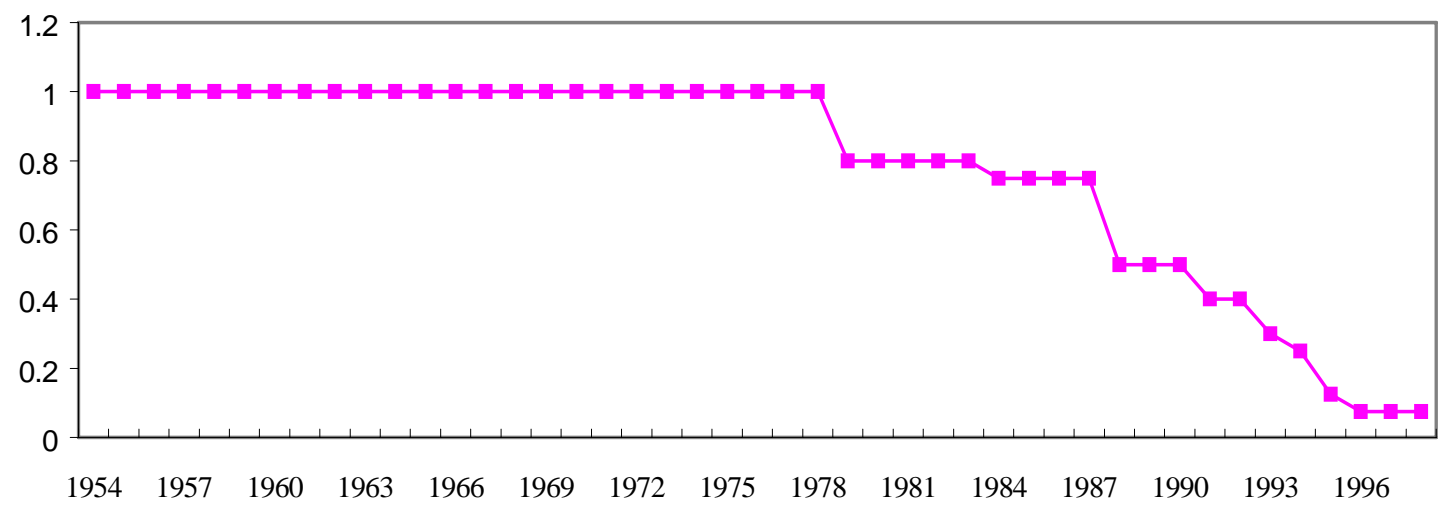

Figure 2: Summary measure of reserve requirements

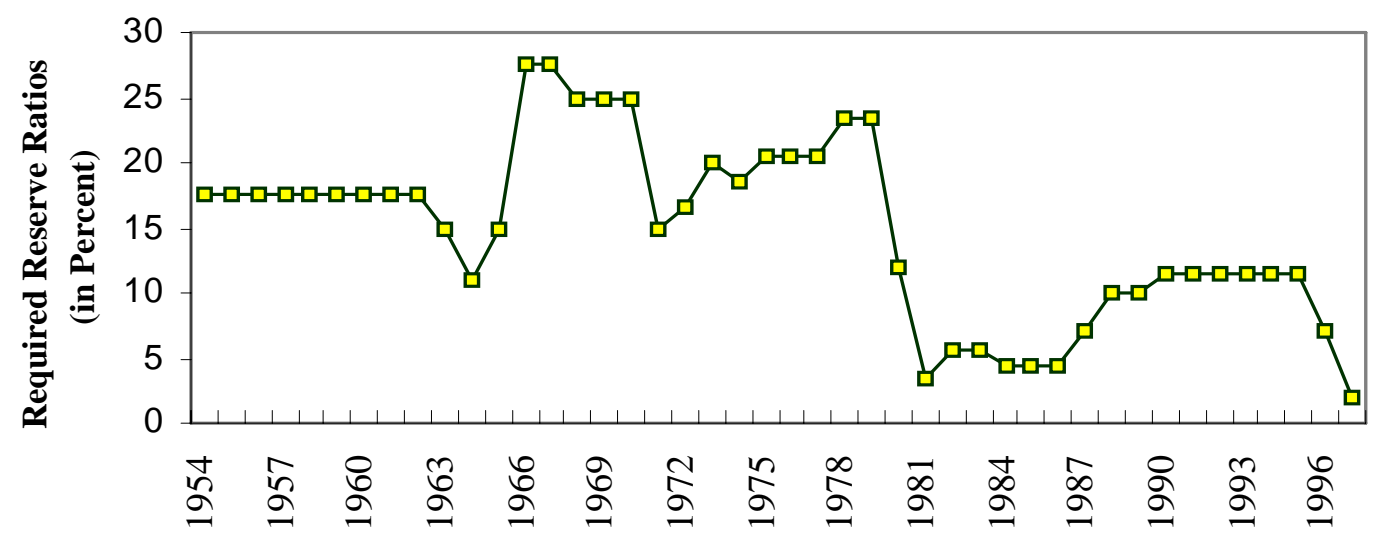

Data on required reserve ratios on $(a)$ demand and $(b)$ time and saving deposits were collected from Bank of Korea Annual Reports (various issues). 5 Because of the very high correlation between the two ratios, we use their arithmetic average as a summary measure of reserve requirements (RR). This measure, illustrated in Figure 2, registers an upward jump during 1966-67, which coincides with the first wave of reforms that saw large increases in interest rates and reserve requirements, resulting in increased state control over the banking system (Harris 1988). RR exhibits a decline during 1968-71 and fluctuates widely in the 1970s. In the early 1980s, the index shows a sharp decline, which coincides with the relaxation of lending rate controls while the 1987-89 period registered considerable increases in reserve requirements. In the 1990s, RR exhibits relative stability to decline significantly in 1997 when reserve requirements on all types of deposits were set at 2 per cent.

5 Luarens and Cardoso (1998) argue that indices based only on the reserve requirement ratio and that do not take into account the continued changes in the tax base cannot capture accurately the restrictiveness of reserve requirements. This argument applies to the Chilean case where authorities have continuously changed the tax base to close loopholes and make the controls more restrictive. In the case of Korea, however, there have been no attempts to change the tax base and as such the index we use in this paper remains valid. 
To test the robustness of our results to the measurement of financial repression, we also use $(a)$ the actual ratio of bank reserves to bank deposits and $(b)$ the inflation rate as alternative proxies of the degree of financial repression (Roubini and Sala-i-Martin 1992, 1995; Haslag and Koo 1999). The ratio of actual bank reserves to bank deposits differs from the required reserve ratio by the amount of excess reserves. Banks may hold excess reserves when there are regulatory restrictions that limit the development of interbank markets or when other regulatory structures push them to do so (Roubini and Salai-Marin 1992, 1995). Thus, the ratio of bank reserves to deposits can serve as a useful proxy of the degree of financial repression (Haslag and Koo 1999). We expect increases in the ratio of actual reserves to deposits to result in an inward shift of the supply of credit to the private sector. The inflation rate acts like a tax on financial intermediation, as it reduces the real rate of return on bank reserves. As noted by Fry (1995), substantial use of the inflation tax has usually been accompanied by high reserve requirements. We measure inflation as the percentage change in the GDP deflator. The data source for bank reserves, demand deposits and the GDP deflator is the International Financial Statistics (IMF 1998: 6).

\subsection{Method of estimation}

All variables were initially subjected to unit root tests, which suggested that the measure of the stock of credit, as well as real GDP, the index of interest rate restraints, reserve requirements, and the ratio of bank reserves to bank deposits are non-stationary. Since these variables contain unit roots, we use a cointegration estimator to estimate the reduced form relationship between them given by equation (4). Specifically, we apply the dynamic ordinary least squares (DOLS) estimator (Saikkonen 1991; Stock and Watson 1993). This estimator is asymptotically equivalent to Johansen's (1988) maximum-likelihood estimator in the case where variables are integrated of order one and there is a single cointegrating vector. Moreover, it has been shown to perform well in finite samples relative to other asymptotically efficient estimators (Stock and Watson 1993). In these circumstances it is known that the Engle-Granger (1987) estimator may exhibit substantial bias (Banerjee et al. 1986; Stock and Watson 1993). DOLS has a further advantage over the Engle-Granger estimator. While the latter suffers from a nonstandard asymptotic distribution (Park and Phillips 1988), the former allows valid and efficient inferences on the parameters of the cointegrating vector. We first apply DOLS to the reduced-form equation (equation 4) and obtain estimates of the cointegrating vector for the credit market. We next compute the predicted long-run equilibrium values and compare them with the corresponding actual stock of real credit, which allows us to construct our measure of disequilibrium credit.

\subsection{Empirical results}

Table 1 reports the results of estimating equation (4) using different sets of explanatory variables. In Model A, we include the index of interest rate restraints and the reserve requirement ratio as indicators of the degree of financial repression. The explanatory variables enter with the expected signs and are statistically significant. The estimated coefficient of real GDP has the expected positive sign, takes a plausible value, and is statistically significant. The interest rate restraints index enters with a negative sign, indicating that relaxation of interest rate controls results in an increase in the equilibrium stock of real credit to the private sector. The reserve requirement ratio 
enters with the expected negative sign and is also statistically significant at the 5 per cent level indicating that higher required reserve ratios are associated with lower credit to the private sector. The equation performs well as reflected in high $\mathrm{R}^{2}$ and passes various diagnostic tests. Finally, according to the Dickey-Fuller and Augmented Dickey-Fuller statistics, the hypothesis of a unit root in the residuals is rejected at the 5 per cent level. Thus, Model A represents a cointegrating relationship.

Table 1: Cointegrating vector for the credit market (sample period: 1954-1997)

\begin{tabular}{|c|c|c|c|c|}
\hline Regressors & Model A & Model B & Model C & Model D \\
\hline Intercept & $\begin{array}{c}-14.825^{\star} \\
(2.256)\end{array}$ & $\begin{array}{c}-19.744^{*} \\
(1.632)\end{array}$ & $\begin{array}{c}-13.158^{*} \\
(1.979)\end{array}$ & $\begin{array}{c}-13.407^{\star} \\
(2.495)\end{array}$ \\
\hline$L Y_{t}$ & $\begin{array}{l}1.431^{*} \\
(0.068)\end{array}$ & $\begin{array}{l}1.580^{*} \\
(0.051)\end{array}$ & $\begin{array}{l}1.387^{\star} \\
(0.059)\end{array}$ & $\begin{array}{l}1.394^{*} \\
(0.074)\end{array}$ \\
\hline$I R L_{t}$ & $\begin{array}{l}-0.463^{\star} \\
(0.166)\end{array}$ & & $\begin{array}{l}-0.577^{*} \\
(0.161)\end{array}$ & $\begin{array}{l}-0.535^{\star} \\
(0.198)\end{array}$ \\
\hline $\mathrm{RES} / \mathrm{DEP} \mathrm{P}_{\mathrm{t}}$ & & $\begin{array}{l}-0.468^{*} \\
(0.221)\end{array}$ & $\begin{array}{l}-0.512^{\star} \\
(0.118)\end{array}$ & $\begin{array}{l}-0.446^{\star} \\
(0.120)\end{array}$ \\
\hline $\mathrm{RR}_{\mathrm{t}}$ & $\begin{array}{c}-0.006^{\star \star} \\
(0.003)\end{array}$ & & & \\
\hline $\mathrm{INF}_{\mathrm{t}}$ & & $\begin{array}{c}0.068 \\
(0.421)\end{array}$ & $\begin{array}{c}0.212 \\
(0.223)\end{array}$ & \\
\hline \multicolumn{5}{|c|}{ Diagnostic tests } \\
\hline Adj- $R^{2}$ & 0.995 & 0.995 & 0.996 & 0.996 \\
\hline $\mathrm{J}-\mathrm{B}$ & $2.518[0.283]$ & $4.35[0.108]$ & $5.844[0.755]$ & $1.007[0.604]$ \\
\hline $\mathrm{Q}(10,0)$ & $7.660[0.568]$ & $14.44[0.110]$ & $0.988[0.610]$ & $7.214[0.614]$ \\
\hline \multicolumn{5}{|c|}{ Cointegration test } \\
\hline DF & $-4.070^{\star}$ & $-4.273^{*}$ & $-5.208^{\star}$ & $-5.038^{\star}$ \\
\hline $\operatorname{ADF}(1)$ & $-3.401^{*}$ & $-4.028^{\star}$ & $-4.771^{\star}$ & $-4.649^{\star}$ \\
\hline
\end{tabular}

Notes: The dependent variable is (the logarithm of) real broad claims on private sector by deposit money banks, development banks, non-bank financial institutions and trust accounts of commercial banks. The GDP deflator deflates this variable.

LY denotes the logarithm of real GDP, IRL is the index of interest rate liberalization; RR is the index of required reserve ratios; RES/DEP is the ratio of bank reserves to deposits, and INF is the inflation rate measured by the percentage change in the GDP deflator. The equation also includes a dummy variable for year 1968 onwards to account for the structural break in the real broad claims series. Figures in parentheses are the adjusted-standard errors for long-run variance (see Hamilton 1994).

The method of estimation is DOLS (Stock and Watson 1993). Given the small number of observations, to avoid over-parameterization we only retain significant lags and leads (Inder 1995).

$\mathrm{J}$-B is Jaques Berra's test for normality; $\mathrm{Q}$ is Ljung-Box test for autocorrelation. Figures in brackets are the $p$-values.

* Significant at the $1 \%$ level; ** Significant at the $5 \%$ level. 
In Model B, we use the inflation rate and the ratio of bank reserves to deposits as alternative indicators of the degree of financial repression. The estimated coefficient of real GDP increases marginally and is statistically significant. The ratio of bank reserves to deposits enters with the expected negative sign and is statistically significant at the 1 per cent level. On the other hand, the inflation rate is not significant at conventional levels. Model B performs reasonably well and passes various diagnostic tests. Furthermore, the hypothesis of a unit root is rejected at the 5 per cent level indicating that Model B forms a cointegrating vector.

In Model C, in addition to the ratio of bank reserves to deposits and inflation, we include the index of interest rate restraints. Interestingly, both bank reserves to deposits and the interest restraints index enter with a significant negative coefficient indicating that these two measures may be capturing different aspects of financial repression. The estimated coefficient of real GDP retains a positive sign and is statistically significant. The inflation rate on the other hand remains statistically insignificant at conventional levels. Model C performs better than the previous models, in that it comfortably passes various diagnostic tests and shows very strong evidence of cointegration. In Model D, we drop the inflation rate, which was found to be insignificant in all the other specifications. Dropping this variable does not alter the results in any significant way.

Table 2 contains five-year averages of the measure of the credit market disequilibrium from 1961 to 1995, based on Model D of Table 1. This measure is obtained by subtracting the predicted long-run equilibrium value of credit from the actual stock of real credit, and expressing this difference as a proportion of real total claims. According to our estimates, the South Korean credit market has been characterized by excess supply of credit in all these periods. Interestingly, the average proportion of excess credit was higher in the 1970s than in the 1980s and 1990s. Also note that during the first half of the 1980s, excess credit declined significantly to 6.66 per cent, but increased again to 14.5 per cent in the second half. Notably, in the period that preceded the crisis, excess credit declined to under 11 per cent, which is lower than the average in the 1970s and almost equal to that of the 1980s. Thus, while our results are consistent with the over-borrowing hypothesis, they warn against an over-simplification of the links between excess credit and the South Korean financial crisis, as our results suggest that the problem of excess credit has persisted for a long time before the crisis. Nevertheless, the existence of excess credit provides some clues, especially if it is examined in conjunction with other developments (Huang and Xu 1999).

Table 2: Estimates of excess supply of credit

\begin{tabular}{lc}
\hline Period & $\begin{array}{c}\text { EXC }_{\mathrm{B}} \\
\text { (\% of real broad claims) }\end{array}$ \\
\hline $1961-1965$ & 16.6 \\
$1966-1970$ & 27.4 \\
$1971-1975$ & 18.9 \\
$1976-1980$ & 15.7 \\
$1981-1985$ & 6.66 \\
$1986-1990$ & 14.5 \\
$1991-1995$ & 10.9 \\
\hline
\end{tabular}

Notes: $\quad E X C_{B}$ is excess supply of credit estimated using Model D in Table 1. 
Table 3: Granger causality tests

\begin{tabular}{|c|c|c|c|}
\hline 3 Lags & F-Test & F-Critical at $5 \%$ & Interpretation \\
\hline EXCESS $\rightarrow$ GPRODUCT & $F(3,23)=4.99$ & 3.05 & \multirow{2}{*}{$\begin{array}{l}\text { Unidirectional causality } \\
\text { from excess credit to } \\
\text { change in capital } \\
\text { productivity }\end{array}$} \\
\hline GPRODUCT $\rightarrow$ EXCESS & $F(3,23)=1.28$ & 3.05 & \\
\hline 4 Lags & & & \multirow{3}{*}{$\begin{array}{l}\text { Bilateral causality } \\
\text { between excess credit } \\
\text { and capital productivity }\end{array}$} \\
\hline EXCESS $\rightarrow$ GPRODUCT & $F(4,20)=4.44$ & 2.87 & \\
\hline GPRODUCT $\rightarrow$ EXCESS & $F(4,20)=5.14$ & 2.87 & \\
\hline
\end{tabular}

Notes: GPRODUCT is the growth in the average productivity of capital where average productivity is measured by the ratio of the flow of current output to the capital stock. EXCESS is excess credit measured by the ratio of real excess supply of credit, estimated using the cointegrating vector of Model D - Table 1, to real broad credit. The Granger causality test was carried over the period 1963-1995. In the EXCESS $\rightarrow$ GPRODUCT line, the F-statistic tests the null hypothesis that the set of estimated coefficients on the lagged EXCESS is not statistically different from zero. In the GPRODUCT $\rightarrow$ EXCESS line, the F-statistic tests the null hypothesis that the set of estimated coefficients on the lagged GPRODUCT is not statistically different from zero.

We next assess whether the credit market disequilibrium could act as an indicator of capital productivity growth. Models of over-borrowing and over-investment predict that over-borrowing will ultimately be reflected in lower productivity growth, perhaps with some lag. The main reason is that borrowed funds are usually used to finance unproductive or even unprofitable projects. To test this implication, we employ a simple Granger causality test between our estimates of credit market disequilibrium and the growth in the average productivity of capital. 6 It is well known that Granger causality tests are very sensitive to the number of lags used in the analysis. Thus in Table 3, we report the results with three and four lags. ${ }^{7}$ As can be seen from Table 3, in the case of three lags, we find unidirectional causality from our estimates of credit market disequilibrium to growth in capital productivity. The results in the case of four lags are slightly different where we find causality running in both directions. While the latter results are difficult to interpret, the evidence of causality from our estimates of credit market equilibrium to growth in capital productivity is consistent with models of overinvestment.

6 We measure the average productivity of capital by the ratio of the flow of current output to the capital stock. Data on the capital stock for the period 1963-90 were obtained from the World Bank Database compiled by Nehru et al. (1993). Capital stock figures from 1991 to 1997 were constructed following the perpetual inventory method assuming a depreciation rate of 4 per cent and uprating the price of capital goods in line with the GDP deflator. Investment and GDP data were obtained from International Financial Statistics (IMF 1998: 6). Excess credit is measured by the ratio of real excess supply of credit, estimated using the cointegrating vector of Model D - Table 1, to real broad credit.

7 Granger tests with 2 lags produce similar results as with 3 lags and hence are not reported here. 


\section{Concluding remarks}

The empirical analysis presented in this paper reveals the existence and persistence of excess credit in the South Korean credit market. These findings are consistent with the hypotheses of over-borrowing or over-investment which may reflect soft budget constraints and/or moral hazard. Our results are also consistent with the hypothesis that over-borrowing can persist as long as firms are able to refinance their unprofitable projects and cash shortfalls. In the 1980s when most of the debt was in local currency, the Korean monetary authorities were able to avert a crisis in spite of the presence of a large volume of non-performing loans, by inflating their way out of the problem (Choi 1993; Nam 1994). By the mid 1990s, this was no longer possible as most of the debt was in foreign currency while international reserves that could cover for them were very low. The unwillingness of foreign banks and investors to renew or rollover credit meant that many firms could no longer finance their unprofitable projects. A conjecture that emerges from our analysis is that while excess credit and over-investment were not by themselves responsible for crisis, their conjunction with high levels of foreign debt and low foreign reserves could have contributed significantly to the South Korean financial crisis.

\section{References}

Banerjee, A., Dolado, J. J., Hendry, D. F. and Smith, G. W. (1986) 'Exploring equilibrium relations in econometrics through state models: some Monte Carlo evidence', Oxford Bulletin of Economics and Statistics, 48: 253-78.

Caprio, G. (1994) 'Banking on financial reform? A case of sensitive dependence on initial conditions', in G. Caprio, I. Atiyas and J. Hanson (eds) Financial reform: Theory and Experience, New York: Cambridge University Press.

Choi, B. S. (1993) 'Financial policy and big business in Korea: the perils of financial regulation', in S. Haggard, C. H. Lee and S. Maxfield (eds) The Politics of Finance in Developing Countries, New York: Cornell University Press.

Corsetti, G., Pesenti, P. and Roubini, N. (1999) 'Paper tigers? A model of the Asian crisis’, European Economic Review, 43: 1211-36.

Demertriades, P. O. and Luintel, K. B. (2001) 'Financial restraints in the South Korean miracle’, Journal of Development Economics, 64: 459-79.

Engle, R. F. and Granger, C. W. J. (1987) 'Cointegration and error correction: representation, estimation and testing', Econometrica, 55: 251-76.

Engle, R. F. and Granger, C. W. J. (eds) (1991) Long-run Economic Relations, Oxford: Oxford University Press.

Fry, M. (1995) Money, Interest and Banking in Economic Development, 2nd edition, London: Johns Hopkins Press Ltd.

Ghosh, S. R. and Ghosh, A. (1999) 'East Asia in the aftermath: was there a credit crunch?', presented at Conference 'The Credit Crunch in East Asia', Washington DC: World Bank.

Greenwald, B. C., Levinson, A. and Stiglitz, J. E. (1993) 'Capital market imperfections and regional economic development', in A. Giovannini (ed.) Finance and Development: Issues and Experience, Cambridge: Cambridge University Press. 
Hamilton, J. D. (1994) Time Series Analysis, Princeton: Princeton University Press.

Harris, L. (1988) 'Financial reform and economic growth: A new interpretation of South Korea’s experience’, in L. Harris (ed.), New Perspectives on the Financial System, London: Croom Helm.

Haslag, J. H. and Koo, J. (1999) 'Financial repression, financial development and economic growth’, Federal Reserve Bank of Dallas Working Paper 99-02.

Hendry, D. F. (1995) Dynamic Econometrics, Oxford: Oxford University Press.

Huang, H. and $\mathrm{Xu}, \mathrm{C}$. (1999) 'Financial institutions and the financial crisis in East Asia', European Economic Review, 43: 903-14.

IMF (1998) International Financial Statistics, CD-Rom. Washington DC: IMF.

Inder, B. (1995) 'Finite sample arguments for appropriate estimation of cointegrating vectors', mimeo: Monash university, presented at the 7th World Congress of Econometric Society (Tokyo).

Johansen, S. (1988) 'Statistical analysis of cointegrating vectors', Journal of Economic Dynamics and Control, 12: 231-54.

Laffont, J. J. and Garcia, R. (1977) 'Disequilibrium econometrics for business loans', Econometrica, 45(5):1187-1204.

Laurens, B. and Cardoso, J. (1998) 'Capital Flows-Lessons from the Experience of Chile’, IMF Working Paper WP/98/168, Washington DC: IMF.

Maddala, G. S. and Nelson, F. D. (1974) 'Maximum likelihood method for models of markets in disequilibrium’, Econometrica, 42:1013-30.

McKinnon, R. and Pill, H. (1997) 'Credible economic liberalization and overborrowing', American Economic Review, 87:189-93.

Nam, S. W. (1994) 'Korea's financial reform since the early 1980s', in G. Caprio, I. Atiyas, and J. Hanson (eds) Financial Reform: Theory and Experience, New York: Cambridge University Press.

Nehru, V. and Dareshwar, A. (1993) 'A new database on physical capital stock: Sources, methodology and results', Revista de Analisis Economico, 8: 37-59.

Park, J. Y. and Phillips, P. C. B. (1988) 'Statistical inference in regressions with integrated processes: Part 1', Econometric Theory, 4:468-97.

Pazarbasioglu, C. (1996) 'A credit crunch? A case study of Finland in the aftermath of the banking crisis’, IMF Working Paper 96/135, Washington DC: IMF.

Roubini, N. and Sala-i-Martin, X. (1992) 'Financial repression and economic growth', Journal of Development Economics, 39: 5-30.

Roubini, N. and Sala-i-Martin, X. (1995) 'A growth model of inflation, tax evasion and financial repression’, Journal of Monetary Economics, 35: 275-302.

Saikkonen, P. (1991) 'Asymptotically efficient estimation of cointegrating regression', Econometric Theory, 7: 1-21.

Schneider, M. and Tornell, A. (2004), 'Balance sheet effects, bailout guarantees and financial crises', Review of Economic Studies, 71(3): 883-913.

Stock, J. H. and Watson M. W. (1993) 'A simple estimator of cointegrating vectors in high order integrated systems’, Econometrica, 61: 783-820. 


\section{Appendix A: Summary of the main financial reforms in Korea}

\section{Interest rates}

6 September 1979 The Monetary Board abolished the existing maximum interest rate on bank loans to make it possible for banks to alter their interest rate on loans. However, the Bankers Association of Korea, considering that banks themselves are not used to determining interest rates, decided to link interest rates on loans to the central bank's rediscount rate.

6 September 1979 The Monetary Board abolished the maximum interest rate on free instalment savings deposits and the maximum interest rate on personal checking deposits.

17 May 1984 The Board allowed seven nationwide commercial banks, local banks, and the Korea Exchange Bank to engage in the negotiable certificate of deposit (CDs) from 1 June.

23 July 1984 A narrow band for loan rates was introduced so that banks could charge different rates according to the creditworthiness of the borrowers.

5 December 1988 Interest rates on loans from banks and non-bank financial intermediaries were fully liberalized.

5 December 1988 Interest rate on time deposits of a maturity greater than two years at banks, postal savings, and credit unions were liberalized.

5 December 1988 Interest rates on time and savings deposits of a maturity greater than one year at mutual savings and finance companies were liberalized.

21 November 1991 Lending rates liberalized further. Lending rates liberalized consisted of those on bank overdrafts; on the discount of commercial bills by banks, mutual savings, and finance companies; on the discount of commercial and trade bills by investment and finance companies; on the purchase of firms' guaranteed papers by banks' trust accounts; and on overdue loans by all financial institutions.

21 November 1991 The liberalization of deposit rates applied to those on short-term, large denomination marketable instruments such as CDs, the sale of large denomination trade bills, commercial paper (CP), and repurchase agreements (RPs).

21 November 1991 The scope of initial liberalization was extended to cover rates on long-term deposits with a maturity of 3 years offered by banks, mutual credit facilities, and credit unions and mutual time deposits with a maturity of two years and more offered by mutual savings and finance companies.

21 November 1991 The issue rates of corporate bonds with a maturity of two years and more were deregulated.

1 November 1993 All lending rates (apart from those financed by the government and the Bank of Korea's rediscounts) were liberalized.

1 November 1993 Rates on long-term deposits with a maturity of at least two years were completely liberalized. 
1 November 1993 Interest rates on debentures and corporate bonds with a maturity of less than two years were liberalized.

1 December 1994 Interest rates on bank and non-bank time deposits with a maturity of one year or more but less than two years were liberalized.

1 December 1994 Banks were permitted to freely set the interest rates on policy loans financed through the aggregate credit ceilings system within their respective prime rates.

24 July 1995 Interest rates on policy-based loans through the aggregate credit ceilings system of Bank of Korea were liberalized.

20 November 1995 The Bank and government freed up the remaining regulated interest rates on bank and non-bank time deposits with a maturity of less than six months and on their instalment deposits with a maturity of less than one year.

19 January 1996 The Bank of Korea lifted the restriction on the size of the premium a bank could charge over its prime lending rate, which had originally been imposed in order to prevent a sharp run-up in bank lending rates in the course of interest rate deregulation.

\section{Developments in money markets}

7 March 1986 The Monetary Board liberalized the rates on negotiable CDs, secured corporate bonds, and bank debentures.

13 February 1987 The Monetary Board reduced the denomination of CDs from 100 million won to 50 million won.

5 December 1988 Interest rates on repurchase agreements, CP of a face value greater than 30 million won and maturity more than 91 days, financial debentures, and corporate bonds were fully liberalized.

5 December 1988 New CP and conventional CP were merged into one.

4 October 1989 The Bank and the government merged the call markets, previously segmented into an interbank market mainly for banks and the over-the-counter market between non-bank financial institutions (NBFIs), which expanded the size of the money market (call markets, CP, CDs, RPs, treasury bills (TBs), and Bankers' Acceptance). After the merger, the interbank rate was fully liberalized.

19 October 1989 The Bank of Korea adjusted the maturity period of CDs issued by banks to other banking institutions from between 91 days and 180 days to between 30 days and 180 days.

21 November 1991 The liberalization of deposit rates applied to those on short-term, large denomination marketable instruments such as CDs, the sale of large denomination trade bills, CP, and RPs.

21 November 1991 The issue rates of corporate bonds with a maturity of two years and more were completely deregulated. 
19 December 1992 The Bank extended the maximum maturity of CDs from 180 days to 270 days.

1 November 1993 Interest rates on financial debentures and those corporate bonds with a maturity of less than two years were liberalized. Government and public bonds and monetary stabilization bonds were also to be issued at prevailing market rates.

3 September 1993 The Bank lowered the minimum denomination of CDs from 50 million won to 30 million won.

18 July 1994 The minimum maturities of CDs and high denomination RPs were shortened from 91 days to 60 days.

24 July 1995 The minimum maturities of short-term financial instruments including CDs, high value RPs, and high value CP were shortened from 60 to 30 days.

\section{Reserve requirements on demand deposits}

Effective 23 November 1987 The Monetary Board raised the minimum reserve requirement from 4.5 per cent to 7 per cent.

20 April 1989 A marginal reserve requirement ratio of 30 per cent on the average increment of demand deposits and time and saving deposits was imposed. The marginal reserve requirements were abolished in February 1990.

15 February 1990 The Bank raised reserve requirement ratios on time deposits, instalment savings deposits with maturity of two years or more and household instalment saving deposit from 7 per cent to 8 per cent. On all other deposits, the reserve requirement ratio increased from 10 per cent to 11.5 per cent.

8 February 1991 The Bank introduced reserve requirements against mutual instalment deposits.

23 April 1996 The reserve requirement on time and savings deposits of more than two years was brought down from 8 per cent to 6 per cent.

23 April 1996 The reserve requirement on checking deposits, pass book deposits, saving deposits, time and saving deposits with a maturity of less than two years was lowered from 11.5 per cent to 9 per cent.

8 November 1996 The reserve requirement on time and savings deposits of more than two years was brought down from 6 per cent to 4 per cent.

8 November 1996 The reserve requirement on checking deposits, pass book deposits, saving deposits, time and saving deposits with maturity of less than two years was lowered from 9 per cent to 7 per cent. 